\title{
A Fresh Look at an Old Problem-Age Discrimination in Employment: Is There A Demographic and Political Trap?
}

\author{
Richard J. Hunter, Jr. (Corresponding Author) \\ Stillman School of Business, Seton Hall University \\ 400 South Orange Avenue \\ South Orange, New Jersey, USA \\ E-mail: hunterri@shu.edu \\ John H. Shannon \\ Stillman School of Business, Seton Hall University \\ 400 South Orange Avenue \\ South Orange, New Jersey, USA \\ E-mail: John.Shannon@shu.edu
}

\author{
Henry J. Amoroso \\ Stillman School of Business, Seton Hall University \\ 400 South Orange Avenue \\ South Orange, New Jersey, USA \\ E-mail: Henry.Amoroso@shu.edu
}

Received: Jan. 22, 2018 Accepted: Feb. 8, 2018 Online published: Feb. 10, 2018

doi:10.5296/jpag.v8i1.12648ＵRL: https://doi.org/10.5296/jpag.v8i1.12648

\begin{abstract}
This article asserts that age discrimination in the workplace remains a major problem in society today. The article traces the origin of legislation protecting older Americans from
\end{abstract}


discrimination in the workplace from its earliest origins at the turn of the twentieth century and outlines the types of age discrimination and the remedies for violations of the federal Age Discrimination in Employment Act of 1967, better known as the ADEA. The article also describes the major exceptions to the legislation and issues relating to ADEA waivers. The article concludes with an analysis of several important legal cases which call into question the vitality of the ADEA today and also offers several suggestions for future legislative and administrative actions in order to assure that the rights of older Americans are fully protected in the workplace.

Keywords: age discrimination, age discrimination in employment act (ADEA), damages, waiver, bona fide occupational qualifications (BFOQ)

\section{Introduction}

Writing in the AARP Bulletin, Fleck (2014) reported that nearly one out of every five workers in the United States is age 55 or older. $64 \%$ of workers indicate that they have personally seen or experienced age discrimination in the workplace. Further, $58 \%$ of adults believe that age discrimination begins among workers as early as in their 50's (Perron, 2013/2014; generally, Bureau of Labor Statistics, 2013).

America experienced a dramatic increase in its elderly population throughout the twentieth century. Improvements in health care attenuated by the passage of both Medicare and Medicaid in 1965 have generated substantial increases in the longevity of many Americans. As Donahue (2003, p. 474) noted: "Coupled with a declining birth rate, census and population experts predict that this rise in the elderly population will translate into twenty-two percent of Americans being over the age of sixty-five by 2030."

Ortman, Velkoff, and Hogan (2014, p. 1) stated that between 2012 and 2050, "the United States will experience considerable growth in its older population." In fact, by the year 2050, the population aged 65 and over is projected to be 83.7 million Americans, which is nearly double its estimate of 43.1 million in 2012. The "baby boomers," those born between 1946 and 1964 (Hogan, Perez and Bell, 2008), are the group that is largely responsible for this increase in the older population, as "boomers" began turning 65 in 2011. If life expectancy matches predictions, life expectancy for females within the next thirty years should be 83-85 and 80 for males (although there are predictions that the predictions may be "off" by as many as nine years for females and six years for males) (Cox, 2009; Olshansky, 2009). Ortman, Velkoff, and Hogan (2014) noted that "By 2050, the surviving baby boomers will be over the age of $85 . "$

The continuing "graying of America" (Sade, 2012) raises important societal questions that touch upon law, politics, and economics. The conflict generated between "consumerism" (Granzin and Grikscheit, 1976), a youth-centered culture, and the considerable political power and perceived wealth of many American seniors has become a central issue in American politics, generating a wide ranging debate concerning social security, retirement security, medical insurance, taxation, school finance, and employment opportunities.

The issue of the wealth of U.S. seniors, however, is in reality a mixed one. "While $11 \%$ of 
senior households have income of $\$ 100,000$ or more and another $2 \%$ of seniors have incomes of $\$ 200,000$ or more, most senior citizens, aged 65 or older, have relatively low household income" (Free By 50, 2012). In 2012, median household income of seniors was \$33,118 compared to a median of $\$ 50,054$ for the entire population. Statista (2018) reports that senior income stood at $\$ 39,823$ in 2016 , as opposed to a median of $\$ 59,039$ for the entire population (see also Coxwell, 2015).

According to the Pension Rights Center, older adults get their retirement income from the following sources:

- Social Security: 85 percent of people 65 and older receive Social Security. The average Social Security income in 2014 was not quite $\$ 1,300$ per month.

- Assets: Sixty-three percent of retirees rely on financial assets for retirement income. According to Retirement USA, "the median amount of asset income for households where either the householder or spouse was aged 65 or older was $\$ 1,542$ for those households who received any asset income. In 2008, 59 percent of older households had income from assets."

- Pensions: Only 32 percent of seniors receive a pension and "this number is trending further downward."

- Earnings: 23 percent of older Americans derive income from work. According to the AARP, the median income earned by retirees from work is $\$ 25,000$ a year. Income from work is the "highest amount of any income source."

- Public Assistance or Veteran's Benefits: About 7 percent of retirees receive assistance from other government sources (Coxwell, 2015).

Issues relating to the age of what has been called "the nation's largest interest group" (Issachharoff and Harris, 1997) raise an important policy question: In the employment setting, should chronological age predict both the "functionality and productivity" of older workers? (Donahue, 2003).

\subsection{Purpose of the Study and Literature Review}

The purpose of this study is to investigate the origins of the various statutory schemes on both the federal and state levels designed to combat age discrimination in employment, outline any exceptions to these schemes, discuss the remedies for employees who prove discrimination based upon age, and discuss several recent developments that may shed light on the question whether age discrimination is still an issue in society today.

The authors have relied on seminal research by Kovarsky and Kovarsky (1974), Griffin (1977), and Lahey (2006) relating to state antidiscrimination laws; the research undertaken by Glenn and Little (2014) relating to the origins of the Age Discrimination in Employment Act; the research of Peeler and Haffner (2015) on work place retaliation; statistics taken from the Bureau of Labor Statistics, the Equal Employment Opportunity Commission, the Department of Labor, and the United States Census Bureau; and several relevant court cases and 
administrative actions.

\section{Combating Age Discrimination: A Brief History}

Interestingly, state legislative initiatives aimed at regulating discrimination against older workers have existed from the beginning of the twentieth century. In 1903, Colorado was the first state to enact legislation prohibiting age discrimination in employment. Friedman (1984) noted that the Colorado statute provided that no employer "shall discharge any individual between the ages of eighteen and sixty years, solely and only upon the basis of age" provided that the employee was "well versed in the [employer's] line of business" and was "qualified physically, mentally, and by training and experience to satisfactorily perform and does satisfactorily perform the labor." Kovarsky and Kovarsky (1974) and Griffin (1977) delineated the jurisdictions which have enacted "operative bans on age discrimination": Colorado (1903); Louisiana (1934); Massachusetts (1937 \& 1950); Rhode Island (1956); Pennsylvania (1956); New York (1958); Connecticut (1959); Wisconsin (1959); Oregon (1959); Puerto Rico (1959); Alaska (1960); Delaware (1960); California (1961); Ohio (1961); Washington (1961); Montana (1961); New Jersey (1962); Nebraska (1963); Hawaii (1964); Maryland (1964); Idaho (1965); Indiana (1965); Maine (1965); Michigan (1965); Nevada (1965); New Hampshire (1965); New Mexico (1965); North Dakota (1965); Kentucky (1966); Illinois (1967); West Virginia (1967); Georgia (1971); District of Columbia (1973); Iowa (1974) (see also Lahey, 2006).

Many of these statutes applied protections to workers between the ages of forty and sixty-five, although several states extended their statutory schemes to discrimination downward as well. For example, the Colorado statute covered ages eighteen to sixty, and the Oregon statute covered ages twenty-five to sixty-five.

State statutory regimes generally prohibited discriminatory practices in hiring, discharging, and in terms and conditions of employment by private employers, labor unions, and employment agencies. Remedies available for violations of the various statutes included criminal penalties, civil remedies in the form of monetary damages, as well as the availability of administrative remedies (for example, consent decrees) in many states (Hasko, Holoch, and Young, 1982; generally Marion, 1982).

However, no federal law made age discrimination illegal (Neumark, 2008). When the Civil Rights Act of 1964 (1964) was enacted, age was originally considered for inclusion as one of Title VII's protections, along with race, creed, color, national origin, and sex. However, a prohibition against discrimination based on age was not ultimately included in the statute. Instead, the Congress directed Secretary of Labor W. Willard Wirtz to undertake a study of age discrimination in employment. In June of 1965, the Secretary issued a report, The Older American Worker: Age Discrimination in Employment (Department of Labor, 1965) relating to employers setting age limits in the hiring process. The report indicated that "nearly one-half of the job openings in the private sector arbitrarily disqualified applicants over the age of fifty-five, while a quarter were closed off to workers over forty-five" (Donahue, 2003, pp. 475-476; generally, Harper, 1997). 
In responding to these and other concerns, Congress conducted a series of hearings on the topic of age discrimination in employment. Glenn and Little (2014) reported that testimony before the Senate General Subcommittee on Labor and Public Welfare in 1967 revealed a number of even more troubling statistics that spurred Congress to take action. As Glenn and Little (2014) noted, "For example, in 1964, applicants over 55 years of age were barred from half of all job openings in the private sector. Workers over 45 were barred from a quarter of these jobs, and workers over 65 were barred from almost all of them." The data presented to Congress also indicated that the problem was actually worsening over time-"jobs were disappearing, and older workers were bearing the brunt of the layoffs. Between 1965 and 1966 alone, the share of workers unemployed for 27 weeks or more that were over age 45 increased from 30.2 percent to 34.3 percent. Older men, it was reported, had been leaving the workforce in droves since 1951" (Glenn and Little, 2014).

As a result, Congress enacted the Age Discrimination in Employment Act (ADEA) in 1967 "to promote employment of older persons based on their ability rather than age; to prohibit arbitrary age discrimination in employment; [and] to help employers and workers find ways of meeting problems arising from the impact of age on employment."' Among the factors prompting the passage of the ADEA identified by Marion (1982) were "the difficulties faced by older workers in trying to retain their jobs and in finding new employment when displaced, the prevalent practice among employers of setting arbitrary age limits unrelated to the ability of employees to perform their jobs, and the high unemployment rate among older workers."

\section{Types of Age Discrimination}

As described as Rocketswag.com (2018, age discrimination may take many forms.

- "Direct discrimination: This is said to take place when an individual is not favored, solely because of his/her age.

- Indirect discrimination: A company or an employer is said to be engaging in indirect discrimination against an employee or an aspirant, if they have a strategy of categorizing individuals of a particular age group by putting them at a disadvantage in comparison to other group of employees or aspirants.

- Harassment: Telling ageist jokes, bullying or name calling solely on the basis of age amounts to harassment.

- Victimization: In this context, an individual is said to be victimized, if he/she is being treated less-favorably because he/she has filed a complaint of age discrimination or he/she has agreed to testify for some other victim of age discrimination" (Rocketswag.com, 2018). This is sometimes referred to as retaliation (Peeler and Haffner, 2015).

Remedies for violations of the ADEA are designed to have a restorative effect (Tecson, 2007). In adjudicating cases under the ADEA, courts are authorized to grant relief "to eliminate the unlawful practices and to restore aggrieved persons to the positions where they would have 
been if the illegal discrimination had not occurred." The Act's goal "is to make persons whole for injuries suffered as a result of unlawful employment discrimination." Indeed, the Act's restorative purpose was reaffirmed by the Fourth Circuit Court of Appeals in Spagnuolo v. Whirlpool Corp. (1983, p. 118) when it held that a court must "grant the most complete relief possible toward putting the victim of age discrimination back into the position he would have been in but for the unlawful discrimination."

England (2018) notes that here are several categories of damages available to employees who are successful in suing their employers for age discrimination. The categories differ under federal and state law, as well as from state to state:

- Lost Back Pay and Future Pay: Under the ADEA and state age discrimination laws, employees who win age discrimination cases may recover any wages they lost as a result of the discriminatory act (Beranbaum, 2003).

- Lost Benefits: A successful plaintiff can recover the financial value of the fringe benefits lost as a result of the discrimination. Both the ADEA and the laws of many states allow awards of such damages.

- Damages for Emotional Distress: Employees who have suffered age discrimination often experience emotional distress. These damages are also called damages for "pain and suffering." However, under the ADEA, a plaintiff is not entitled to damages for emotional distress. Damages for emotional distress may be available under a state age discrimination law (Cockerham, 2017; Dean v. American Security Insurance Co. (1977); contrast Vaughan v. Anderson Regional Medical Center (2014) with Pineda v. JTCH Apartments, LLC (2016)).

- Punitive Damages: Punitive damages are intended to punish an employer for intentional discrimination. As England (2018) notes, "Punitive damages are only available in particularly egregious cases." The ADEA does not allow employees to collect punitive damages. However, some states allow employees who bring successful age discrimination cases to win punitive damages. In these cases, a plaintiff will be required to meet a higher standard of proof than is required to prove the underlying discrimination or retaliation claim itself.

- Attorneys' Fees: Under the ADEA and some states' laws, a successful plaintiff may also be awarded attorneys' fees (Villescas v. Richardson, 2001; Rupe and Malone, 2017).

The ADEA initially provided protections for workers between the ages of forty to sixty five, which was later raised to seventy in 1978. The upper age limit was eliminated altogether in 1986 (Cheeseman, 2002, pp. 557-558). However, the age threshold has remained at 40 throughout the revisions (Woodruff, 1995; Cheeseman, 2002).

The enactment of the ADEA did not end the debate or employment discrimination against 
older Americans. In fact, many would argue that the ADEA resulted in numerous unintended consequences. Donahue (2003) pointed to several issues that seem to have persisted throughout the next four decades. First, while the statute was clearly aimed at combating discrimination based on age in the hiring process, "less than nine percent of the cases filed in the 1980's involved a refusal to hire." Instead, 76\% involved wrongful terminations. Second, "far from assisting older workers who would otherwise become dependent on the state if they were unemployed," the typical litigants in ADEA cases were "overwhelmingly white male professionals and managers who earn high salaries." Finally, although an expressed concern of the ADEA "was to improve the long-term employment of older workers as a group, there appears to be little evidence that the ADEA has alleviated the unemployment problem for older workers" (Donahue, 2003, p. 476).

Sok (2014) bolsters this view and reported that the unemployment rate for persons over the age of 55 increased sharply with the onset of the recession of 2007, and reached a high of 7.2 percent in December 2009. In addition, older persons who became unemployed spent more time searching for work. Workers aged 55 years and older had an average duration of joblessness of 35.5 weeks, compared to 23.5 weeks for those aged 16-24 and 30.3 weeks for those aged 25 to 54 years. In addition, older Americans are continuing to return to the labor force in record numbers. Mosisa and Hipple (2006) reported that the rising labor force participation among older persons is likely part of a long term pattern that began in the mid-1990s. Sok (2014) notes that for "persons aged 55 years or older, the labor force participation rate increased from a low of 29.2 percent in 1993 to a peak of 40.4 percent in May 2009." Sok (2014) also posits that the increase in labor force participation reflects "the need of many near retirees to work after large losses in their retirement accounts and the need for older workers in general to ensure adequate postretirement incomes to address increased life spans." In addition, Purcell (2005) stated that the move by employers to replace defined-benefit retirement plans with defined-contribution retirement plans allowed employers to shift more responsibility for retirement income to the employee from the employer. In many cases, this change necessitated a large number of seniors to return to work and a return to consideration of issues under the ADEA.

\section{Exceptions to the ADEA-"Bona Fide Occupational Qualifications" [BFOQ] or "Reasonable Factors Other Than Age" [RFOA]}

The ADEA does not create an absolute prohibition against all aged-based employment decisions. In fact, the Act provides that it is not unlawful for an employer to discriminate on the basis of age "where age is a bona fide occupational qualification reasonably necessary to the normal operation of the particular business" [BFOQ] (Fischman, 1986) or under circumstances "where the differentiation is based on reasonable factors other than age" [RFOA] (EEOC, 2012; see also Pfutenreuter, 2009). For example, "under provisions of the ADEA, state and local governments retain the right to set mandatory retirement ages for public safety officers such as police and firemen" (Pynes, 2015, p. 35; see also Fitz v. First Tennessee Production Credit Association, 1989).

The Act also allows employers to "observe the terms of a bona fide seniority system (Eckles $v$. 
Consolidated Rail Corp., 1996) [or] to observe the terms of a bona fide benefit plan" where such plans are not used as a pretext or subterfuge (Enlow v. Salem-Keizer Yellow Cab Co., 2004) by an employer to discharge an employee on the basis of age where the employee is otherwise qualified. Finally, an employer is permitted to "discharge or otherwise discipline an individual [employee] for good cause" (Harpring v. Continental Oil Co., 1980).

Donahue (2003, pp. 508-509) notes that despite precise guidance by the legislative history of the Act, in cases where an employer is asserting a BFOQ defense (e.g., International Union v. Johnson Controls, 1991), the employer must show:

(1) "The qualification is reasonably necessary to the essence of the employer's business; and

(2) That all or substantially all workers in the protected category are unable to perform the job or that individualized assessment is highly impractical."

Interestingly, with reference to the RFOA exception, the First Circuit Court of Appeals stated in Loeb v. Textron, Inc. (1979): "[The] age statute was not meant to prohibit employment decisions based on factors that sometimes accompany advancing age, such as declining health or diminished vigor and competence." However, it is important to note that a terminated employee under the RFOA exception may still have a cause of action under the Americans With Disabilities Act (1990) which requires employers to provide "reasonable accommodations" to disabled employees (Hood, 1998; Moberly, 2008; MacDonald, Fabian, and Dong, 2010; Hunter and Shannon, 2016). (Retired) Judge Richard Posner (1995, p. 339) noted: "The ADA may succeed in helping older workers where the ADEA has been ineffective."

In addition, an employer may require an employee who has attained the age of 65 to retire under certain discreet circumstances - the so-called "benefits plan" exception (EEOC v. Home Insurance Co., 1982; Reinhart, 1987). In order for this exception to be valid: 1) there must be a bona fide plan in effect; 2) the action must have been taken in observance of its terms; and 3) the plan must have not been a subterfuge to avoid the purpose of the statute (EEOC v. Home Insurance Co., 1982, p. 252). The "benefits plan" exception may be recognized in cases where an employee has been serving in an executive leadership position or a high-policy making position for at least two years preceding the mandatory retirement. However, under these conditions, the employee must earn a retirement income on an annual basis that is greater than or equal to an established statutory amount.

Assessing the validity of the "benefits plan" exception has been problematic. In judging this exception courts will inquire whether early retirement incentive plans are legally permissible based upon a careful evaluation of the question of voluntariness (Henkel, 2000) - especially as many employers required their employees who accepted such a plan to waive all possible ADEA claims (e.g., Harper, 1993; Feuer, 2005). In response, Congress passed the Older Workers Benefit Protection Act (1990), enacted to prohibit discrimination with regard to employee benefits, to ensure that a worker who had released his or her employer from an age discrimination claim had done so in a "knowing and voluntary" manner (see Oubre v. Energy Operations, 1998). 


\section{Macrothink}

The Older Workers Benefit Protection Act (1990) addresses four different release scenarios: 1) a release by an involuntarily terminated employee who has not filed an Equal Employment Opportunity Commission (EEOC) charge or lawsuit; 2) releases by employees who are involuntarily terminated under group reductions in force and who have not filed age discrimination claims or lawsuits; 3 ) releases in settlement of disputed claims, either pending EEOC charges or civil lawsuits; and 4) releases by employees who have voluntarily opted to sever employment under an incentive program (Burch v. Fluor, 1994; HR Hero, 2018).

Title II of the Act sets forth specific threshold requirements for procurement of a valid ADEA waiver.

The statute specifies that, at a minimum, a release must:

1. be "written in a manner calculated to be understood" by the employee;

2. refer specifically to rights and claims available under the statute;

3. not waive prospective claims;

4. provide consideration in exchange for the release beyond something of value the employee is already entitled to;

5. advise the employee, in writing, to consult with an attorney;

6. give the employee at least 21 days to consider the agreement (or at least 45 days in the case of an exit incentive or other group termination program such as a Reduction in Force or RIF);

7. give the employee at least seven days to revoke the agreement; and

8. in the case of an exit incentive or other group termination program, contain information regarding: (a) the "job titles and ages of all individuals eligible or selected for the program, and the ages of all individuals in the same job classification or organizational unit who are not eligible or selected for the program;" (b) any eligibility factors for the program; and (c) any time limits applicable to the program.

\section{Is Age Discrimination Still A Significant Problem?}

Has age discrimination abated as an issue in the American economy? The U.S. Equal Employment Opportunity Commission (2018a; 2018b) reported the following statistics relating to ADEA claims in 2016:

Complaints received:

Total Resolutions (including prior years):

Resolutions by type:

Settlements:

Withdrawals with benefits:

Administrative Closures:

No reasonable cause determinations

Reasonable Cause found:

Successful conciliations:

Unsuccessful conciliations:

Merit resolutions (favorable to a plaintiff)

Monetary benefits:
20,857

22,594

1,445

1,252

3,729

15,548

620

339

281

3,317

$\$ 88.2$ million 
Farrell (2017) stated that "Age discrimination is widespread, well documented and, sadly, deeply entrenched in the American workplace.... Unfortunately, federal courts have also increasingly made age discrimination claims difficult to prove." Farrell (2017) continued that the "Supreme Court and many lower courts increasingly defer to employers on hiring and employment decisions when it comes to what the ADEA calls "reasonable factors other than age."

\subsection{The United States Supreme Court Weighs In}

An important change in the perspective of the United States Supreme Court relating to the issue of age discrimination came in the "landmark" 2009 Supreme Court ruling in Gross v. FBL Financial Services (2009). Jack Gross, an employee of FBL Financial Services, Inc., was transferred to another position and a former subordinate took on many of Gross' former responsibilities. They both received the same compensation, but Gross maintained that his reassignment under these circumstances amounted to a demotion. Gross brought suit against FBL in April 2004 in federal District Court, claiming ADEA violations. The trial court found in his favor and awarded him $\$ 46,945$ in lost compensation. The United States Court of Appeals for the Eighth Circuit reversed the decision. The United States Supreme Court affirmed the decision of the Eighth Circuit, finding that a plaintiff must prove by preponderance of evidence, that age was the "but for" cause of the adverse employment action. In essence, the Supreme Court held that a claimant in an age discrimination case must prove that age discrimination was the primary factor behind a bias claim (see also University of Texas Southwestern Medical Center v. Hassan, 2013). Gosselin (2017) noted that "The high court's decision will make it harder for some people later in their work lives to prove they were victims of bias."

Then, in 2016, the United States Supreme Court's decided to let stand a lower court ruling in Villarreal v. R.J. Reynolds Tobacco (2016, Court of Appeals).

Richard Villarreal had applied online for a territory sales manager job at R.J. Reynolds Tobacco when he was 49 years old. Villarreal received no response to the application. Several years later, Villarreal learned about the company's internal guidelines stating that the ideal candidate would be "2-3 years out of college." "Outside" individuals who were charged with reviewing job applicants were told to "stay away from" applicants whose resumes showed they had been "in sales for 8-10 years." The trial court dismissed Villarreal's suit saying the ADEA claim he had brought only protected existing employees, not job applicants. The court also agreed with the defendant that Villarreal had not "diligently" pursued the reason why he didn't hear back about his application. The United States Supreme Court refused to grant certiorari in the case, thus letting stand the lower court ruling (Villarreal v. R.J. Reynolds Tobacco, 2017, United States Supreme Court).

Based on the rulings in Villarreal and Goss, is fair to conclude that the promise of the ADEA has turned into any empty one for America's aging worker population, at least as far as the United States Supreme Court is concerned? 
There is one glimmer of hope-but it may lie with the EEOC rather than the courts. The EEOC did act aggressively in the Texas Roadhouse discrimination case it brought in 2011 against the steakhouse chain (Mollica and Sagafi, 2017). The EEOC had filed suit seeking relief for a class of applicants the EEOC charged had been denied front-of-the-house positions, such as servers, hosts, server assistants and bartenders, because of their age, 40 years and older. The EEOC (2017) alleged that the Kentucky-based company had "a history of labeling workers over 40 such things as 'Old 'N Chubby' and rejecting them for jobs where customers see them."

After the district court judge declared a mistrial in February due to a deadlock among the jurors, Texas Roadhouse agreed to a settlement with the EEOC (EEOC v. Texas Roadhouse, Inc., 2017). Texas Roadhouse agreed to pay $\$ 12$ million and to change its hiring and recruiting practices.

In addition to the monetary relief, the consent decree, which will be in force for three and a half years, includes an injunction preventing Texas Roadhouse from discriminating on the basis of age in the future. The agreement also requires the company to establish a diversity director and pay for a decree compliance monitor, who is charged with ensuring that the company complies with the decree's terms. The terms of the consent decree require Texas Roadhouse to comply with the ADEA and to increase its recruitment and hiring of employees age 40 and older for front-of-the-house positions.

However, it should be remembered that this settlement was negotiated under the Obama administration, prior to the election of President Donald Trump. Will it be possible to continue to advance the interest of older Americans under these changed circumstances? In an atmosphere of perceived hostility to workers' rights in the marketplace, might the Trump administration decide that acting to protect the rights of its aged working population might be in their best political interests, considering the considerable voting power of American seniors?

\section{Some Commentary and Suggestions for Moving Forward}

Harper (2013), among others, has proposed a number of changes or "reforms" to the ADEA that would provide it with the same procedural and substantive strengths that Congress has provided under Title VII relating to damages, remedies, class actions, defenses, and causation standards. There are several substantive actions that the Congress, the Administration, or the EEOC could undertake to strengthen worker protections for older Americans:

- Congress could pass the bipartisan Protecting Older Workers Against Discrimination Act (2012), originally introduced by now-retired Senator Tom Harkin of Iowa, which was aimed at restoring the legal standards for age discrimination claims to the pre-Gross days. Foreman (2010) is especially critical of the Gross case. He asserts that the Court's majority engaged in an "unabashed display of judicial lawmaking" in which the majority disregarded 
both congressional intent and decades of judicial precedent, eroding important protections for seniors and relegating them to "second class status" among victims of discrimination.

- Congress, in conjunction with the EEOC, could also amend the ADEA to broaden the Act to include all firms - not just those with 20 or more employees. On the administrative front, the EEOC could return to an aggressive stance on enforcing the ADEA. This, of course, will depend on President Trump's appointees to the Commission.

- The EEOC should recognize what is known as "safe harbor" hiring where older workers would be hired over a two-or three-year probationary period and could be discharged without cause or consequence for the employer under the ADEA during that time. During that period, management might be persuaded that they had underestimated the value of seasoned workers (Harper, 2013).

Estreicher (2017) argues that "The benefit of the safe-harbor approach is that it directly addresses the concerns that materially influence the employer's non hiring decision."

- Congress could also move to fully fund ADEA provisions for re-education and training programs to help older workers get hired that had not been funded under the President's budget (Sewell and Rugaber, 2017).

In addition, states could revitalize their efforts in combating age discrimination, which in turn could become a model for future revisions of federal law (Sperino, 2013).

Economics, ironically, may be the strongest impetus towards positive change. After a period of eight years of steady economic growth which has brought the U.S. unemployment rate to $4.1 \%$ (January 2018), employers are once again seeking workers, of which seniors make up a significant percentage. These workers deserve to be treated fairly and equitably in the workplace and to be assured of the protection of their right to be free of discrimination and the decidedly negative effects of age stereotypes (Hazen Paper v. Biggins, 1993; Johnson, 2009) by both the courts and the Equal Employment Opportunity Commission. And one more factor: Seniors vote in large and perhaps disproportionate numbers to other groups in society! While seniors make up $32 \%$ of the adult population, they make up $36 \%$ of the electorate (Seniorsmatter, 2018).

\section{References}

Age Discrimination in Employment Act. (1967). 29 U.S.C. Sections 621-634.

Americans With Disabilities Act. (1990). 42 U.S.C. Section 12101.

Automobile Workers v. Johnson Controls. (1991). 499 U.S. 107 (United States Supreme Court).

Beranbaum, J. A. (2003). Economic damages in an employment case: Calculations and 
assumptions.

[Online]

Available:

https://www.bestlawyers.com/Content/Downloads/Articles/2211_1.pdf (January 12, 2018).

Burch v. Fluor Corporation. (1994). 867 F. Supp. 873 (District Court, Eastern District of Missouri).

Bureau of Labor Statistics. Available: https://www.bls.gov/ (Accessed January 14, 2018).

Cheeseman, H. R. (2002). The legal and regulatory environment (Third edition). Upper Saddle River, N. J.: Prentice Hall.

Civil Rights Act of 1964. (1964). Public Law 88-352.

Cockerham, W. S., \& Brockhoeft, L. (2018). Are pain and suffering and punitive damages recoverable under the ADEA and FLSA? The 5th circuit issues inconsistent decisions. Healthcare Law Insights [Online] Available: https://www.healthcarelawinsights.com/category/labor-employment (February 27, 2018)

Cox, L. (2009). We will live longer in 2050. ABC News.com [Online] Available: http://abcnews.go.com/Health/ActiveAging/humans-live-longer-2050-scientists-predict/story ?id=9330511 (January 11, 2018).

Coxwell, K. (2015). Average retirement income 2016: How does it compare to your plans? New Retirement [Online] Available: https://www.newretirement.com/retirement/average-retirement-income-2016-how-does-it-co mpare-to-your-plans/ (December 1, 2015).

Dean v. Anderson Security Insurance Co. (1977). 564 F.2d 97 ( $5^{\text {th }}$ Circuit Court of Appeals).

Department of Labor. Available: https://www.dol.gov/ (Accessed January 14, 2018).

Donahue, J. J. (2003). Foundations of employment discrimination law (Second edition). New York: Foundation Press.

Eckles v. Consolidated Rail Corp. (1996). 94 F.3d 1041 ( $7^{\text {th }}$ Circuit Court of Appeals).

EEOC v. Home Insurance Co. (1982). 672 F.2d 252 (2 ${ }^{\text {nd }}$ Circuit Court of Appeals).

EEOC v. Texas Roadhouse, Inc. (2017). Case No.:1:11-cv-11732-DJC.

England, D. C. (2018). Damages for winning an age discrimination case. Nolo.com [Online] Available:

https://www.nolo.com/legal-encyclopedia/damages-winning-age-discrimination-case.html (Accessed January 11, 2018).

Enlow v. Salem-Keizer Yellow Cab Co. (2004). 389 F.3d 812 ( $9^{\text {th }}$ Circuit Court of Appeals).

Estreicher, S. (2017). Achieving antidiscrimination objectives through 'safe harbor" rules for cases of chronic hiring aversion. Journal of Law \& Public Affairs, 2, 1-12.

Farrell, C. (2017). Supreme Court turns its back on age discrimination, Next Avenue [Online] Available: 
http://www.nextavenue.org/the-supreme-court-turns-its-back-on-age-discrimination/ (July 13, 2017).

Feuer, A. (2005). When are releases of claims for ERISA plan benefits effective? The John Marshall Law Review, 38, 773-866.

Fischman, R. L. (1986). BFOQ defense in ADEA suits: scope of 'duties of the job. Articles by Maurer Faculty, Paper 870. Available: http://www.repository.law.indiana.edu/facpub/870 (Accessed January 10, 2018).

Fitz v. First Tennessee Production Credit Association. (1989). 861 F.2d. 884 (6 ${ }^{\text {th }}$ Circuit Court of Appeals).

Fleck, C. (2004). Forced out, older workers are back. AARP Bulletin [Online] Available: https://www.aarp.org/work/on-the-job/info-2014/workplace-age-discrimination-infographic.h tml (May 2004).

Foreman, M. L. (2010). Gross v. FBL Financial Services - Oh so gross! University of Memphis Law Review, 40(4), 681-704.

Free by 50. (2012). Household income distribution for senior citizens. Free by 50 [Online] Available: $\quad$ http://www.freeby50.com/2012/12/household-income-distribution-for.html (December 12, 2012).

Friedman, L. M. (1984). ADEA and ADA assessed, in Foundations of employment discrimination law, 494-497 (John J. Donahue III, ed.).

Glenn, J. J., \& Little, K. (2014). A study of the age discrimination in employment act of 1967. GPSolo [Online], 31(6). Available: https://www.americanbar.org/publications/gp_solo/2014.html

Gosselin, P. (2017). Supreme Court won't take up R.J. Reynolds age discrimination case, Pro Publico [Online] Available: https://www.propublica.org/article/supreme-court-rj-reynolds-age-discrimination-case (June 26, 2017).

Granzin, K. L., \& Grikscheit, G. M. (1976). What is consumerism? Advances in Consumer Research, 3, 68-72.

Griffin, P. (1977). The problem of involuntary retirement before age 65. Marquette Law Review, 60(4), 1053-1082.

Gross v. FBL Financial Security. (2009). 557 U.S. 167 (United States Supreme Court).

Harper, M. C. (1997). ADEA doctrinal impediments to the fulfillment of the Wirtz report agenda. University of Richmond Law Review, 31, 757-793.

Harper, M. C. (2013). Reforming the Age Discrimination in Employment Act: Proposals and prospects. Employee Rights and Employment Policy Journal, 16(1), 13-49.

Harpring v. Continental Oil, Co. (1980). 628 F.2d 406 ( $5^{\text {th }}$ Circuit Court of Appeals). 
Hasko, J., Holoch, A., \& Young, N. (1982). Bibliography: Gerontology and the law: A selected bibliography. Southern California Law Review, 56, 289-ff.

Hazen Paper v. Biggins. (1993). 506 U.S. 604 (United States Supreme Court).

Henkel, J. W. (2000). Waiver of claims under the Age Discrimination in Employment Act after Oubre v. Energy Operations, Inc. Wake Forest Law Review, 35, 395-423.

Hogan, H., Perez, D., \& Bell, W. R. (2008). Who (really) are the first baby boomers? Joint Statistical Meeting Proceedings, Social Science Section (American Statistical Association), 1009-1016. Available: https://www.census.gov/prod/2010pubs/p25-1138.pdf.

HR Hero. (2018). HR guide to employment law: a practical compliance reference manual covering 14 topics, including discrimination. [Online] Available: http://topics.hrhero.com/older-workers-benefit-protection-act-owbpa/ (Accessed February 7, 2018).

Hunter, R. J., \& Shannon, J. H. (2016). The confluence of the Americans with Disabilities Act and administrative law: The case of the recalcitrant or perhaps dangerous employee. Texas Tech Administrative Law Journal, 18(1), 83-101.

International Union v. Johnson Controls. (1991). 499 U.S. 187 (United States Supreme Court).

Issachharoff, S., \& Harris, E. W. (1997). Is age discrimination really age discrimination? The ADEA's unnatural solution. New York University Law Review, 72, 780-837.

Johnson, J. (2009). Reasonable factors other that age: the emerging specter of ageist stereotypes. Seattle University Law Review, 33, 49-91.

Kovarsky, I., \& Kovarsky, J. (1974). Economic, medical, and legal aspects of the age discrimination laws in employment. Vanderbilt Law Review, 27(5), 839-926.

Lahey, J. (2006). State age protection laws and the Age Discrimination in Employment Act. NBER Working Paper 12048. https://doi.org/10.3386/w12048

Loeb v. Textron, Inc. (1979). 600 F.2d 1003 ( $1^{\text {st }}$ Circuit Court of Appeals).

MacDonald, W. K. L., Fabian, E. S., \& Dong, S. (2010). Best practices in developing reasonable accommodations in the workplace: findings based on the research literature. The Rehabilitation Professional, 16(4), 221-232.,

Marion, J. H. (1986). Legal and equitable remedies under the Age Discrimination in Employment Act. Maryland Law Review, 41(2), 298-351.

Moberly, M. (2008). The disability history mystery: assessing the employer's reasonable accommodation obligation in "record of disability" cases. Pepperdine Law Review, 35, 1-45.

Mollica, P., \& Sagafi, J. C. (2017). Texas Roadhouse age bias trial shows relevance of ADEA, Law $360 \quad$ [Online] Available: https://www.outtengolden.com/texas-roadhouse-age-bias-trial-shows-relevance-of-adea 
(February 2, 2017).

Mosisa, A., \& Hipple, S. (2006). Trends in labor force participation in the United States. Monthly Labor Review, 35-57 [Online]. Available: https://www.bls.gov/opub/mir/2006/10/art3abs.htm/ (October 2006).

Neumark, D. (2008). The Age Discrimination in Employment Act and the challenge of population aging. NBER Working Paper 1437. Available: http://www.nber.org/papers/w14317 (Accessed January 13, 2018). https://doi.org/10.3386/w14317

Older Workers Benefit Protection Act. (1990). 29 U.S.C. Section 623 (Amending the Age Discrimination in Employment Act).

Olshansky, S. J., et al. (2009). Aging in America in the 21st century: Demographic forecasts from the MacArthur Foundation research network on an aging society. Trends in labor force participation in the United States. Milbank Quarterly, 87(4), 842-862. https://doi.org/10.1111/j.1468-0009.2009.00581.x

Ortman, J. M., Velkoff, V., \& Hogan, H. (2014). An aging nation: the older population in the United States. United States Census Bureau (Current Population Reports) [Online] Available: http://www.census.gov (Accessed January 12, 2018).

Oubre v. Energy Operations, Inc. (1998). 522 U.S. 422 (United States Supreme Court).

Peeler, R., \& Haffner, E. (2015). Selected developments in retaliation law. [Online] Available: https://www.Americanbar.org/contact/dam/aba/events/labor-law/2015/november.

Perron, R. (2013/2014). Staying ahead of the curve 2013 (updated 2014). AARP multicultural work and career study. [Online] Available: https://www.aarp.org/research/topics/economics/info-2014/staying-ahead-curve-work.html/ (February 2013/July 2014).

Pfutenreuter, R. H. (2009). The curious case of disparate impact under the ADEA: Reversing the theory's development into obsolescence. Minnesota Law Review, 94(2), 467-504.

Pineda v. JTCH Apartments, LLC. (2016). 843 F.3d 1062 (5 $5^{\text {th }}$ Circuit Court of Appeals).

Posner, R. A. (1995). Age discrimination by employers and the issue of mandatory retirement in Aging and old age (Richard A. Posner, ed.). Chicago: University of Chicago Books (Chapter 13).

Protecting Older Workers Against Discrimination Act. (1967). Senate 2189 (112th Congress).

Purcell, P. (2005). Older workers: Employment and retirement trends. Congressional Research Service [Online]. Available: http://aging.senate.gov/crs/pension34.pdf (September 14, 2005).

Pynes, J. E. (2015). The ADEA and its exemptions on the mandatory retirement provisions for firefighters. Review of Public Personnel Administration, 34-45.

Reinhart, B. (1987). Interpreting section 4(f) (2) of the ADEA: Does anyone have a "plan"? 
University of Pennsylvania Law Review, 135, 1055-1087. https://doi.org/10.2307/3312055

RocketSwag.com. (2018). Types of age discrimination. RocketSwag.com [Online] Available: http://www.rocketswag.com/retirement/elderly-law/age-discrimination/Types-Of-Age-Discri mination.htm (Accessed February 6, 2018).

Rupe, A., \& Malone, K. (2017). Examining damages in ADEA retaliation claims. [Online] Available:

https://www.law360.com/articles/927805/examining-damages-in-adea-retaliation-claims.

Sade, R. M. (2012). The graying of America: challenges and controversies. Journal of Law and Medical Ethics, 40(1), 6-9. https://doi.org/10.1111/j.1748-720X.2012.00639.x

Seniorsmatter. (2018)/ Older Americans voting patterns. [Online] Available: http://seniorsmatter.com/older-americans-voting-patterns/ (Accessed January 15, 2018).

Sewell, D., \& Rugaber, C. A. (2017). In US, factory jobs are high-tech, but the workers are not. Associated Press (Business News) [Online]. Available: https://www.inddist.com/news/2017/08/us-factory-jobs-are-high-tech-workers-are not (August 17, 2017).

Singer, J. (2014). The battle for the senior vote. Daily Kos [Online] Available: http://www.dailykos.com/story/2014/10/26/1337541/-The-battle-for-the-senior-vote (October $26,2014)$.

Sok, E. (2004). Record unemployment among older workers does not keep them out of the job market. U.S. Bureau of Labor Statistics [Online] Available: https://www.bis.gov/opub/ils/summary_10_04/older_workers.htm (Accessed February 6, 2018).

Spagnuolo v. Whirlpool Corp. (1983). 717 f.2d 114 ( $4^{\text {th }}$ Circuit Court of Appeals).

Sperino, S. (2013). Revitalizing state discrimination laws. George Mason Law Review, 20, 545-590.

Statutory Materials

Tecson, D. J. (2007). Federal remedies in employment discrimination actions. [Online] Available: http://www.chuhak.com/37D475/images/stories/PDFs/ch9tecson.pdf (Accessed January 12, 2018).

U.S. Census Bureau. Available: https://www.census.gov/ (Accessed January 14, 2018).

United States Department of Labor. (1965). The older American worker: age discrimination in employment.

Available:

https://openlibrary.org/works/OL639356W/The_older_American_worker_age_discrimination _in_employment (Accessed February 7, 2018).

United States Equal Employment Opportunity Commission (2018a). Age discrimination in employment act (charges filed with EEOC). Available: 


\section{Macrothink}

Journal of Public Administration and Governance ISSN 2161-7104 2018, Vol. 8, No. 1

https://www.eeoc.gov/eeoc/statistics/enforcement/adea.cfm (Accessed January 8, 2018).

United States Equal Employment Opportunity Commission (EEOC). (2012). EEOC issues final rule on RFOA. Available: http://www.eeoc.gov/eeoc/newsroom/release/3-29-12.cfm (March 29, 2012).

United States Equal Employment Opportunity Commission. (2018b). Facts about age discrimination. Available: https://www.eeoc.gov/facts/age.html (Accessed January 12, 2018).

University of Texas Southwestern Medical Center v. Nassar. (2013). 570 U.S. 338 (United States Supreme Court).

Vaughan v. Anderson Regional Medical Center. (2017). 849 F.3d 588 (5 ${ }^{\text {th }}$ Circuit Court of Appeals), cert denied, 2017 U.S. Lexis 4193 (United States Supreme Court).

Villarreal v. R.J. Reynolds Tobacco. (2016). 839 F.3d 958 (11 ${ }^{\text {th }}$ Circuit Court of Appeals).

Villescas v. Richardson. (2001). 145 F. Supp.2d 1228 (United States District Court for the District of Colorado).

Woodruff, B. B. (1973). Unprotected until 40: the limited scope of the age discrimination in employment act of 1967. Indiana Law Journal, 73(4), 1295-1312.

\section{Copyright Disclaimer}

Copyright for this article is retained by the author(s), with first publication rights granted to the journal.

This is an open-access article distributed under the terms and conditions of the Creative Commons Attribution license (http://creativecommons.org/licenses/by/4.0/). 